\title{
Macroeconomic Determinants of Balance of Payments in Namibia
}

\author{
Joel Hinaunye Eita (Corresponding author) \\ Department of Economics, Monash University South Africa \\ Private Bag X60, Roodepoort, 1725, South Africa \\ Tel: 27-119-504-054Ｅ-mail: joel.eita@monash.edu or hinaeita@yahoo.co.uk
}

Tel: 264-6122-4622Ｅ-mail: mihe.gaomab@nacc.com.na or mihe.gaomab@gmail.com

Received: August 25, 2011

Accepted: October 26, $2011 \quad$ Published: February 1, 2012

doi:10.5539/ijbm.v7n3p173

URL: http://dx.doi.org/10.5539/ijbm.v7n3p173

\begin{abstract}
This paper investigates macroeconomic determinants of the balance of payments in Namibia for the period 1999 to 2009. The investigation was conducted through cointegrated vector autoregression methods. The investigation reveals that fiscal balance, GDP and interest rate are the main determinants of balance of payments in Namibia. Increase in GDP and interest rate causes an improvement in the balance of payments. The positive effect of GDP on balance of payments suggests that expansion of export has a positive impact on current account and the overall balance of payments. More increased export potential through the development of new products and services should be encouraged. The positive impact of interest rate on balance of payments suggests that interest rate can be used as a policy tool to ensure favourable capital account and for improved balance of payments. An improvement in the fiscal balance is also associated with an improvement in the balance of payments. This implies that policymakers need to assess the forecast of SACU receipts in order to ensure readiness proactively when these receipts decline to avoid a possible macroeconomic, fiscal and balance of payments instability.
\end{abstract}

Keywords: Balance of payments, Fiscal balance, Interest rate, Current account, Capital account, Cointegration, VECM

\section{Introduction}

Balance of payments (BOP) is an account that records the value of goods and services, capital movements, including foreign direct investments, and other items that flow into or out of a country (Carbaugh, 2008: 3). It gives an indication of how much has been spent by Namibian consumers and businesses on imported goods and services and how successful the Namibian companies have been exporting to other countries (Note 1). It is an important measure of the relative performance of Namibia in the global economy.

The trend analysis shows that the overall balance of payments in Namibia has shown largely surpluses during the period of 2002 to 2007. This arose mainly from significant current account surpluses due to sizeable inflows from mineral export receipts on account of exchange rate movements and increased revenue receipts from the Southern African Customs Union (SACU). Hence, excluding the SACU receipts, the balance of BOP shows somewhat a volatile and negative trend characterized by a negative merchandise trade account balance with a volatile and increasingly positive current account balance.

The quantitative analysis done on the microstates such as Namibia (Imam, 2008: 3-27) reveals that small economies are characterized by high volatile movements in BOP account balances largely due to terms of trade shocks and their economic structural features (Note 2). Although much research has been written generically to justify such factors to the volatile movements in BOP of a small economies, there is no independent empirical and quantitative research done on Namibia to ascertain the determinants of the movements of the BOP. Therefore this study is pioneering in the sense that there has not been any analytical study done to explicitly 
study the determinants of the overall BOP in Namibia.

This paper therefore attempts to analyze empirically and quantitatively what macroeconomic variables determine the movements on the overall balance of payments (BOP) accounts with a view to provide valuable policy recommendations necessary to ensure a sustainable and stable BOP for the foreseeable future. Such policy recommendations will be analyzed within the context of the predictable future declines in the SACU receipts and what effect it will have on the overall BOP of Namibia. The paper will specifically focus on the following research objectives:

- To analyze the trends of the BOP and identify significant factors during the period 1999 till 2009

- To identify the economic variables influencing overall balance of payments in Namibia, using both theoretical and empirical frameworks.

- To ascertain which determinants are significant for BOP stability and which may be useful as a policy recommendation.

The study is organised as follows. Section 2 provides analysis and identification of significant factors of the trends of the balance of payments account in Namibia. Section 3 reviews the theoretical and empirical approaches of the balance of payments. This is followed by Section 4 that discusses data and econometric methodology. Section 5 provides estimation results. Section 6 concludes.

\section{Trend Analysis of the Balance of Payments in Namibia}

\subsection{Overall Balance of Payments}

The overall balance of payments including the transfers from SACU has been negative from 2002 until 2005. The situation however improved in 2006 due to an increase of N\$4.7 billion (Namibia dollar, N\$4.7 billion) in the current account that was mainly attributable to an increase of $\mathrm{N} \$ 2.1$ billion in the SACU receipts. The BOP account is heavily reliant on the SACU receipts as reflected in Figure 1. When SACU receipts are excluded, the BOP becomes negative, with a huge debit balance reported in 2006. This came as a result of an increase of $\mathrm{N} \$ 2.1$ billion in the SACU receipts in the same year, as compared to insignificant increase in these transfers during the preceding years. The impact of the SACU receipts on the BOP account is clearly visible in Figure 1, when this amount increased by a mere $\mathrm{N} \$ 703$ million in 2007, reflecting a slight improvement in the overall balance of payments. The 2007 improvement in the overall balance of the BOP was also attributable to an increase in direct equity investment, which rose by $\mathrm{N} \$ 918$ million during the same period. The impact of the SACU receipts should be considered as alarming since the inflows of such receipts have significance on the overall BOP balance of Namibia.

\subsection{Current Account}

The current account improved since 2002 and recorded surpluses that were attributable to strong mineral export proceeds, net inflows in services (mainly tourism related) and SACU receipts. Since 2002, Namibia has been a net importer of goods and services, reporting merchandise trade deficits, except in 2006 where a net surplus of N\$642 million was recorded. Increase in imports came largely as a result of high cost of imported fuel and imported durables and non durables, of which $85 \%$ is largely from South Africa (Bank of Namibia, 2007). Figure 2 presents the trends in the current account. Merchandise imports were mainly dominated by machinery and equipment, whilst the export account was mainly boosted by mining output, with diamond output accounting for a larger portion.

The services account recorded volatile surpluses since 2002, with the lowest surplus of N\$277 million reported in 2005 , and the highest amount of $\mathrm{N} \$ 1$ billion reported in 2005 . The volatility was attributable to the decrease in inflows paid for services offered by locally based operators, especially in the transport sector, relative to foreign operators (Bank of Namibia, 2007).

Current account transfers boosted the BOP over the years. Included in these transfers are funds from the SACU pool as well as grants for development assistance. The overall current account balance increased from N\$1.3 billion reported in 2002 to N\$7.4 billion reported in 2007 due to huge current account transfers.

\subsection{Capital and Financial Account}

The capital and financial is presented in Figure 3. The capital and financial account reported deficits for the period 2002 - 2009, with the highest deficit of N\$7.0 billion reported in 2006. Foreign direct investment in Namibia mainly equity capital in the mining sector as well as reinvested earnings increased by $\mathrm{N} \$ 2.2$ billion in 2007, the largest increase recorded since 2002. Deficits in the portfolio investment increased over the years with the highest amount of $\mathrm{N} \$ 10.4$ billion reported in 2007 . This increase was observed mainly in the equity 
investment instruments that recorded a growth rate of $61.6 \%$, and debt securities, which increased by $16.7 \%$ in 2007. Invested funds were supplied by institutional investors, especially pension, insurance and unit trust funds who invest mainly in South Africa through asset management companies, with another portion invested offshore in search of better returns on their portfolios. Other investments include loans for the Government, banks and other sectors. Both the long and short-term investment has been volatile during the period under review, with net outflows reported in 2004 and 2007 whilst other years recorded small surpluses. When assessing separately the current and capital accounts, it is noteworthy that the current account balance inclusive of the SACU Receipts is the driver of the positive balance of payments movement whereas the capital and financial accounts remain in deficit.

The situation of a positive current account balance offset by a deficit on the capital and financial account has become a structural feature of the Namibian economy. This reflects a chronic excess savings over investment in the economy, which in turn has led to an outflow of capital over the years. The deficit on the capital and financial account has been driven mainly by the outflow of insurance and pension fund money to South Africa. This situation (of excess savings over investment) is rather atypical for a developing country where the opposite situation is normally the case and it can be explained by the relatively high savings in relation to investment.

The challenge facing Namibia is how to redress the situation by creating more investment opportunities that will stimulate economic growth and development. It is also noteworthy that current transfers have played a key role in Namibia's current account balance being positive while the trade balance traditionally has been in a deficit, due to the imports of mainly consumption goods.

\section{Theoretical and Empirical Approaches}

\subsection{Theoretical Approach}

There are many theoretical approaches to analyse the balance of payments. In order to discern such analysis, it would be useful to distinguish such theoretical approaches on the two components of BOP, namely the current and capital account. In the current account, the first common theoretical approach to mention is based on the competitive nature of the economy thus termed the competitiveness approach, based on the elasticity or sensitivity of trade. This approach is viewed from an explicit premise of an economy in equilibrium in terms of trade. This means that in equilibrium, exports of Namibia is equal to its imports. Exports depend positively on the exchange rate (defined as number of units of domestic currency to a unit of foreign currency), whereas imports depend negatively on it (exchange rate). The competitiveness approach clearly shows that the terms of trade can be influenced by a change in exchange rate. The size of the swing in the trade balance depends on the export and import elasticities (Iley and Lewis 2007:15) but this approach was developed within a framework of the fixed exchange rates, such as the Bretton-Woods system and cannot operate under a free floating regime as the exchange rate change is completely endogenous. Namibia follows a fixed exchange rate pegged to the South African Rand, of which its Reserve Bank has a fair degree in principle to influence the exchange rate using political means.

The above theoretical approach shows that the foreign exchange rate can have an influence on the current account of the BOP. Another factor affecting the merchandise trade balance is the prices of Namibian goods as compared to the prices of the same products charged by its foreign competitors. If inflation rate in Namibia exceeds inflation in other countries that Namibia trades with, then ceteris paribus, Namibian goods will be less competitive and the quantity of Namibian exports will decrease. Inflation also reduces the demand for Namibian dollars at each given exchange rate. The demand for Namibian products is also affected by global prices of products that Namibian producers export. The income, population and the rate of economic growth in importing countries can also influence this demand. The level of imports in Namibian can also be attributable to increased wealth now that many people enter the job market and can afford to buy goods. Growth in the number of those employed can lead to strong consumption growth. Such factors can have also have a bearing on the capital account and its effect may or may not be similar as in the case of the current account. Regardless of the simple theoretical model indicated above, the macroeconomic identity "savings minus investment $=$ capital account balance which should in turn equals exports minus imports"= trade balance. This indicates that any macroeconomic factors such as the exchange rate and inflation can have an impact on both the current and capital accounts which in turn can have implications on foreign reserves. Clausen and Kandil (2004) disentangle the current account and financial account to show how complex the causal relations in the balance of payments are. They also show that both balances react differently to cyclical fluctuations and are correlated negatively to each other. This is illustrated in Figure 3 of Section 2.3 which provides such compelling graphical evidence where there is a scissor like movements of the Namibian current and capital accounts during the period 1999 
-2009 .

Corden (2007: 366) assessed a microeconomic, utility maximising framework to analyse the determinants of a current account imbalance in which he asserts that individual utility considerations are also driving saving and investment decisions which have implications for the capital account balance. These can therefore lead to imbalances in the capital account and current account. The decisions to save and to invest are determined by macroeconomic stability as well as by institutional features such as governance structures, the validity of the rule of law, capital market developments and microeconomic factors, such as labour market regulation.

A very important approach to the balance of payments is developed by Kallon (1994). Kallon (1994) described the general framework of the balance of payments. The simple open economy LM model is employed in order to derive the long-run balance of payments equation. The equation is specified as follows:

$$
Y_{t}=\alpha_{1} R_{t}+\alpha_{2} G_{t}+\alpha_{3} P_{t}^{m}+\alpha_{4} Y_{t-1} ; \quad\left(\alpha_{1}<0 ; \alpha_{2} ; \alpha_{3} ; \alpha_{4}>0\right)
$$

Equation (1) is the commodity market equilibrium. It is assumed to depend on the domestic interest rate $\left(R_{t}\right)$, government expenditure $\left(G_{t}\right)$, relative price of imported goods $\left(P_{t}^{m}\right)$, and the real income of the previous period $\left(Y_{t-1}\right)$. The money market equilibrium $(\mathrm{LM})$ is specified in Equation (2) as:

$$
M_{t}=\beta_{1} Y_{t}+\beta_{2} R_{t}+\beta_{3} P_{t} ; \quad\left(\beta_{1}>0 ; \beta_{2} ; \beta_{3}<0\right)
$$

The money market equilibrium in Equation (2) depends on real income $\left(Y_{t}\right)$, domestic interest rate $\left({ }^{R_{t}}\right)$ and domestic inflation rate $\left(P_{t}\right)$. According to Kallon (1994), the balance of payments equilibrium depends on real income $\left(Y_{t}\right)$, relative price of imported goods $\left(P_{t}^{m}\right)$ and the differential between domestic interest rate and the summation of foreign interest rate and expected change in the exchange rate. The balance of payments equilibrium is specified as follows:

$$
B O P_{t}=\delta_{1} Y_{t}+\delta_{2} P_{t}^{m}+\delta_{3} R_{t}^{N} ; \quad\left(\delta_{1}<0 ; \delta_{2} ; \delta_{3}>0\right)
$$

Where $R_{t}^{N}=f\left(R_{t}, R_{t}^{*}, E_{t}\right) ; R_{t}, R_{t}^{*}, E_{t}$ are domestic interest rate, foreign interest rate and exchange rate.

\subsection{Empirical Approach and Model for Namibia}

\subsubsection{Empirical Approach}

The empirical analysis shows that in the context of considering macroeconomic and institutional drivers of the balance of payments, it is normally the macroeconomic factors that are regularly researched on and that the institutional dimension is regularly overlooked. It's only recent that some research areas looking at the adjustment implications of the microstates (Imam, 2008, 13). The institutional related aspects such as financial deepening of capital markets and other natural disasters have been considered as factors determining the current account balances. Macroeconomic factors such as inflation, domestic credit and exchange rates are also considered in this study. Of significant interest is the variable on the fiscal balance whereby its positivity suggests increased national savings and improved government budget balance which leads to improvement in the current account balance. This is particular of immense interest since SACU receipts which is considered a transfer in the balance of payment account of Namibia does raise the government budget balance and does indeed improve the current and balance of payment accounts.

Draper and Freytag $(2008,3)$ focussed on the intertemporal approach when analysing the dynamics and policy conclusions of the South African current account deficit since 2002. The institutional and microeconomic drivers of structural change and its policy challenges are in the centre of the analysis. The exchange rate also plays a major role in this dynamic process. It is seen as an adjustment parameter to manage the transfer from a change in the capital account to the corresponding change in the current account in South Africa. The real exchange rate in this context is defined as the domestic relative price of tradables $\left(\mathrm{P}_{\mathrm{T}}\right)$ and non-tradables $\left(\mathrm{P}_{\mathrm{N}}\right)$ respectively (Note $3)$.

In the context of Namibia, (Miyajima, 2007, 25, IMF), Namibia's competitiveness position was evaluated using the widely applied traditional indicator, the real effective exchange rate (REER) by comparing it to its equilibrium level. The study found that the current level of Namibia's REER does not suggest a competitiveness problem but there are other structural and institutional related issues that are more significant such as education attainment, export performance and the business environment. The study concluded that by improving its competitiveness, Namibia can become more competitive globally. The study on microstates that includes 
Namibia as part of the estimated panel (Imam, 2008, 18) concluded that whilst it is straightforward from theory that exchange rate policies matter in explaining movements on the current account, the results show that the exchange rate channel for a microstate is not important and that also the structural features (e.g. the limited manufacturing base, level of capital market development), institutional factors (such as wage rigidities and inflexible labour markets) probably accounts for much of the explanation. What is interesting to note from this study is that Microstates that runs a fiscal surplus due to raised national and public savings tend to account significantly for movements on the current and balance of payments and further tend to induce rapid adjustment when there is a disequilibrium as a result for example from a terms of trade shock.

A study by Iyambo and Kalenga (2003) that ascertain the revenue losses from SACU due to the South Africa European Trade and Development Cooperation Agreement does indicate that such losses have profound implications for the fiscal balance and will ultimately negatively affect the balance of payments position. Early studies conducted in 1997 however did not take into account of the import effect of the trade agreement. Large volumes of imports due to increased domestic demand and low inflation as well as interest rates have resulted in the SACU pool growing despite the fact that the trade pact became effective in 1999. This somewhat compromises the end objective of the research as there were no revenue losses encountered and there was no evidence to prove that it caused balance of payments instability. It is also noteworthy that the increased SACU transfers on the current account balance out weighted the persistent capital outflows that undermine the capital account of Namibia. This raises an interesting question as to what ultimately determines the movements on Namibia's balance of payments. Given the theoretical and empirical analysis, what are the key macroeconomic variables that play a more important role on the movements of the balance of payments?

\subsection{Empirical Model for Namibia}

Finding an appropriate model for the balance of payments is not an easy task. Following a review of the theoretical literature and empirical approach for Namibia, this study adopts a general framework described by Kallon (1994). As previously mentioned, very little is known about the relationship between the balance of payments and macroeconomic variables in Namibia. The balance of payments function adopted in this study is a combination of monetarist, structuralists and fiscalist factors. The long-run balance of payments equation for Namibia is specified as follows:

$$
B O P_{t}=\gamma_{0}+\gamma_{1} D C_{t}+\gamma_{2} F B_{t}+\gamma_{3} Y_{t}+\gamma_{4} E R_{t}+\gamma_{5} I R_{t}+\varepsilon_{t}
$$

Where $B O P_{t}, D C_{t}, F B_{t}, Y_{t}, E R_{t}, I R_{t}, \varepsilon_{t}$ are balance of payments, domestic credit, fiscal balance, GDP, exchange rate, interest rate and error term.

Real exchange rate is assumed to be negative because of price differentials in the sense that a depreciation of the real exchange rate means that domestic prices are increasing slower than foreign prices. Hence exports will become more attractive and imports more expensive and this leads to a trade surplus and ultimately to a positive balance of payments position. The inflation rate is thus not included in the estimation as its effect is felt indirectly via the real exchange rate. Including such a variable would have yielded multicollinearity and this would have compromised the diagnostic tests of proper functional form specification. The interest rate is assumed to be positive since an increase in domestic interest rate would have yielded an improved BOP position on account of the capital inflow, but the effect would also be set off by what happens to the current account in the context of interest cost becoming more and having a negative impact on the BOP account through reduced productive capacity. There is a reasonable expectation that the instantaneous impact of interest rate will be felt through the capital account rather than the current account, thus making the positive effect of interest rates on BOP plausible.

An improved fiscal balance is a sign of higher national savings which can lead to the improvement in the current account as earlier indicated. This can also be a sign of increased foreign direct investment which results in increased domestic tax collection and thus an improved fiscal balance. For estimation purposes, it is assumed that an improved fiscal balance is positively correlated with improved current account balance on account of increased national savings as a result of the increased SACU receipts. This will improve the overall balance of payments.

The coefficient on domestic credit is expected to be negative because increased credit growth for a small open economy such as Namibia is normally a sign of stimulated domestic import demand, thus leading to a worsening of the current account balance which ultimately worsens the balance of payments. The coefficient of GDP growth is expected to be positive. However, this depends on the transmission mechanism of the impact of growth on the balance of payments. In terms of the current account, increased GDP growth could be a sign of export 
expansion (thus making trade balance and BOP positive) or sign of faster import growth (thus making trade balance and BOP negative) depending on causality. It can also be a sign of increased foreign direct investment through the capital account particularly if the economy is poor, or it could be due to increased use of domestic savings if the economy is rich. However, this depends again on causality.

\section{Data and Econometric Methodology}

\subsection{Data}

This study uses quarterly data and covers the period 1999 to 2009. The balance of payments (BOP), domestic credit (DC) proxied by credit extended to the private sector, fiscal balance (FB), exchange rate, GDP and interest rate proxied by treasury bills were obtained from various issues of Bank of Namibia's Annual Report and Quarterly Bulletin.

\subsection{Econometric Methodology}

Before the estimation of Equation (4), the time series properties of the variables which involve unit root tests needs to be established. This study uses Augmented Dickey Fuller (ADF) test statistic in order to determine whether the variables to be used in the estimation are stationary or non-stationary.

This study applies vector autoregression (VAR) method. This model has advantages in the sense that time series can be modelled simultaneously. The VAR methodology corrects for autocorrelation and endogeneity parametrically using vector error correction model (VECM) specification. According to Johansen $(1988 ; 1995)$, the advantage of this method is that it prevents substantial bias that takes place in OLS estimates of cointegration relations when the Engle-Granger two step procedure is used. This procedure (Johansen econometric methodology) develops as follows. The starting point in VAR of order $m$ is given by:

$$
z_{t}=\mu+A_{1} z_{t-1}+\ldots \ldots \ldots . . . A_{m} z_{t-m}+v_{t}
$$

Where $z_{t}$ is $(n \times 1)$ vector of variables, each of $A_{i}$ is an $(n \times n)$ matrix of parameters, $v_{t}$ is a residuals or $(n \times$ 1) vector of innovations. This type of modelling estimates the dynamic relationships among variables which are jointly endogenous without the imposition of strong a priori restrictions (Sims, 1980). This argument is supported by Harris (1995). Equation (5) can be re-written in a vector error correction model (VECM) format as:

$$
\Delta z_{t}=\mu+\prod z_{t-1}+\sum_{j=1}^{m-1} \Gamma_{i} \Delta z_{t-i}+v_{t}
$$

where $\prod=\sum_{i=1}^{m} A_{i}-I$ and $\Gamma_{i}=-\sum_{j=i+1}^{m} A_{j}$.

It is assumed that Equation (6) contain only I(0) or stationary variables and is a white noise because the terms in Equation (5) are all I(1). Harris (1995) states that specifying the system this way will have information on the short-run and long-run adjustments to changes in $z_{t}$ through $\Pi$ and $\Gamma_{i}$ estimates. In the analysis of VAR, $\prod$ is a vector representing a matrix of long-run coefficients. This is very important in the analysis of VAR. The long-run coefficients are defined as multiple of two $(n \times r)$ vectors, $\alpha$ and $\beta^{\prime}$ (Eita and Jordaan, 2010). $\Pi=\alpha \beta^{\prime}$, where the elements of $\alpha$ are called adjustment parameters in the VECM. They are loading matrices and denote the speed of adjustment to equilibrium. The elements of $\beta^{\prime}$ are a matrix of long-run equilibrium such that the term $\beta^{\prime} z_{t}$ in Equation (6) represents up to $n-1$ economic equilibrium or cointergrating relationships in the model. If the $\prod$ has rank of zero, it indicates that the variables in $z_{t}$ are not cointegrated. If the rank is $r$ (number of cointegrating vectors), there will $r$ possible stationary relationships. If the matrix has a full rank, the rank is $r=n$ and it suggests that there are $n$ cointegrating vectors and all variables in equation are $\mathrm{I}(0)$. Johansen $(1988 ; 1995)$ proposed two likelihood ratio test statistics for cointegration and these are trace $\left(\lambda_{\text {trace }}\right)$ and maximum eigenvalue $\left(\lambda_{\max }\right)$.

\section{Estimation Results}

\subsection{Unit Root Test}

The univariate characteristics of the data which involves unit root test is the first step before estimation of the regression equation. The variables are tested for unit root using the ADF test statistic. They are presented in 
Table 1. The results of Table 1 show that the all variables (except BOB and DC) are nonstationary in levels. They become stationary on first difference. This means that they are I(1)

\subsection{Cointegration Test and VECM Results}

Cointegration is the next step after establishing the univariate characteristics (time series properties) of the data. This paper applies Johansen cointegration test using two statistics, trace $\left(\lambda_{\text {trace }}\right)$ and maximum eigenvalues $\left(\lambda_{\max }\right)$. The lag length of the variables was set at 1 . It is based on Akaike information criterion, Schwartz information criterion, final prediction error and log likelihood ratio. The diagnostic statistics were performed on the unrestricted VAR and the VECM and results indicate that residuals are multivariate normal, no heteroscedasticity and no serial correlation. The results of cointegration test are presented in Table 2.

Table 2 shows that the trace statistic indicates that there are two cointegrating vectors, while the maximum eigenvalues found one cointegrating vector for a model with intercept and no trend. Since there is evidence of cointegration, it is appropriate to proceed to the VECM. The long-run part of Equation (4) is visualised in Equation (7).

$$
\prod z_{t-1}=\alpha \beta^{\prime} z_{t-1}=\left[\begin{array}{cc}
\alpha_{11} & \alpha_{12} \\
\alpha_{21} & \alpha_{22} \\
\alpha_{31} & \alpha_{32} \\
\alpha_{41} & \alpha_{42} \\
\alpha_{51} & \alpha_{52} \\
\alpha_{61} & \alpha_{62} \\
\alpha_{71} & \alpha_{72}
\end{array}\right]\left[\begin{array}{lllllll}
1 & 0 & \beta_{31} & \beta_{41} & \beta_{51} & \beta_{61} & \beta_{71} \\
0 & 1 & \beta_{32} & \beta_{42} & \beta_{52} & \beta_{62} & \beta_{72}
\end{array}\right]\left[\begin{array}{l}
B O P_{t-1} \\
\ln D C_{t-1} \\
F B_{t-1} \\
\ln E R_{t-1} \\
\ln Y_{t-1} \\
\ln I R_{t-1} \\
C
\end{array}\right]
$$

The first cointegration relation is the long-run balance of payments equation, while the second is the domestic credit equation. The results of the estimated long-run balance of payments equation are presented in Equation (8). The t-statistics are in brackets.

$$
\begin{aligned}
B O P_{t}= & -62.56+0.13 F B_{t}-0.14 \ln E R_{t}+6.38 \ln Y_{t}+3.20 \ln I R_{t} \\
& (-7.40) \quad(3.30) \quad(-0.11)
\end{aligned}
$$

The results show that the main significant determinants of the balance of payments are the fiscal balance, GDP growth and interest rates. The results show that a one percent improvement in fiscal balance will lead to an increase or improvement on BOP by 0.13 percent. This finding is certainly plausible in the Namibian context that a significant part of government revenue comes from SACU receipts and this transfer has significant implications on the balance of payment movements.

The coefficient of exchange rate is negative. This is contrary to theoretical expectations. It indicates that a depreciation of the exchange rate causes worsening of the balance of payments. The exchange rate is found to be highly statistically insignificant. This supports the empirical analysis observed earlier on that the impact of the nominal exchange rate and the price differentials between domestic and foreign prices does not seem to play a strong role in terms of the movements on the balance of payments although the coefficient implies that exchange rate movements does have a negligible impact on balance of payments. This result is understandable since the instantaneous impact of the exchange rate is felt on both the current and capital accounts but its impact can only become significant over a lagged period of perhaps over three or four quarters.

The coefficient on GDP is positive and statistically significant. A one percent increase in GDP causes the balance of payments to improve by 6.38 percent. The positive impact of GDP is a sign of export expansion. Increase in export makes the trade balance and balance of payments positive. Interest rate has positive impact on the balance of payments. An increase in interest rate by one percent causes the balance of payments to increase (improve) by 3.2 percent. This is consistent with theoretical expectations that a positive interest rate would attract capital inflow and improve the balance of payments. These results compare fairly with those obtained in the literature. It is important to note that domestic credit has a zero coefficient on balance of payments because it is a dependent variable in the second cointegrating vector. 
The results of the second cointegrating vector (which is domestic credit equation) are presented in Equation (9). It is important to mention that the second cointegrating vector is not the equation of much interest, because the focus of this paper is on the balance of payments equation (determinants of the balance of payments).

$$
\begin{aligned}
\ln D C_{t}= & -12.50+0.00 F B_{t}-0.11 \ln E R_{t}+1.98 \ln Y_{t}+0.02 \ln I R_{t} \\
& (-4.39) \quad(1.61) \quad(-0.29)
\end{aligned}
$$

Equation (9) shows that increases in income and interest rates are associated with increase in domestic credit expansion by 1.98 and 0.02 percent. Depreciation of the exchange rate causes domestic credit to decrease by 0.11 percent. Fiscal balance has a very low coefficient on domestic credit.

Table 3 presents the estimated $\alpha$ values or the loading matrices. The loading matrices are adjustments coefficients which play a role in bringing the dependent variable to equilibrium. Adjustment coefficients that have values of 0 mean that the variables in question do not play a role in bringing the dependent variable to equilibrium. They do not impact on the dependent variable in the short run. The loading matrices elements relate to the issue of weak exogeneity. According Enders (2004), if a variable does not respond to movements away from the equilibrium it is weakly exogenous. The loading matrices with values of 0 indicate that the variables in question are weakly exogenous.

Table 3 shows that in the first cointegrating vector, fiscal balance exchange rate, GDP and interest rate are weakly exogenous. They do not play a role in bringing the balance of payments to equilibrium. However, balance of payments and domestic credit are not weakly exogenous. They play a role in the adjustment of the balance of payments to equilibrium. It is important to state that the coefficient of the balance of payment is the error correction term, which is negative and statistically significant. This indicates adjustment to equilibrium. In the second cointegrating relation (domestic credit), balance of payments, exchange rate and interest rate are weakly exogenous. Domestic credit, fiscal balance and GDP are not weakly exogenous, but they move the system away from equilibrium.

\section{Conclusion}

The purpose of this study was to determine the macroeconomic effects on the movements of the balance of payments in Namibia. The study found that the main significant determinants of the balance of payments are the fiscal balance, interest rate and GDP growth. The study further found that the exchange rate seem not to be playing a direct role to the determination of BOP in Namibia and ascribed it according to empirical and theoretical analysis to other institutional and economic factors. The results show that there are macroeconomic determinants such as the fiscal balance, interest rate and GDP growth that have a strong bearing on the movement of balance of payments in Namibia. The study found that as expected that the SACU receipts in the form of transfers does have significant influences on the fiscal balance as well as on the current account and movements on the balance of payments accounts. It can therefore be concluded that the sustainability of the Namibian current account deficit will not be endangered immediately in the light of sustained SACU receipts at the moment but cautions that the balance of payments crisis on an unsustainable basis will be a definite reality if SACU receipts decline for the foreseeable future.

There is need on the part of policymakers to assess the forecasts of the SACU receipts in order to proactively ensure readiness if and when SACU receipts decline to avert a possible macroeconomic, fiscal and balance of payments instability. The study found that GDP growth has a positive impact on the balance of payments. The positive impact of GDP on the balance of payments is a sign of export expansion. Increase in export cause the current account and the overall balance of payments to improve. This suggests that a more increased export potential through developing products and services for exportable market should be encouraged. This can assist in ensuring positive terms of trade shock in the event of a drastic SACU receipts decline accompanied by high import demand which can have long run inflationary implications. The study shows that the interest rate has a positive effect on the balance of payments. This means that interest rate should be used as a policy tool to ensure a favourable capital account balance or for increased foreign direct investment and improve the overall balance of payments.

From a policy perspective, the study cautions that Namibia should guard against allowing the status quo to continue as balance of payments sustainability is anchored on increased transfers from SACU and that its current account remains highly subject to strong import demand shocks and movements on the capital account does not seem to respond due interest rate to movements. This remains a matter of policy concern if Namibia wants to strengthen its competitiveness and ensure that this can only be done if it sustains its balance of payments on a 
stable basis. To ensure realisation of a stable and sustainable BOP it is important to conduct a prudent fiscal policy, accelerate structural reforms aimed at increasing export potential and develop early warning financial and macroeconomic surveillance to caution against adverse future SACU receipts declines. Ignoring all these policy concerns can undoubtedly lead to chronic, volatile and unstable balance of payments movements which would threaten macroeconomic stability, economic growth and developmental potential of the Namibian economy.

The major drawback from this study is that it should have estimated separately the determinants of current and capital accounts. This would have allowed one to get a sense of how variables behaved on one account to the other in order to relax some of the a priori assumptions to run the balance of payment estimation. This study is however ground breaking and pioneering since it has come up with a theoretical and empirical framework of the determinants on the balance of payments in Namibia and has furthermore quantitatively assess their relationships. The unavailability of consistent time series data is also another limitation of this study. The use of advanced econometric methodologies requires availability of longer and consistent time series data. Without consistent and longer time-series data, the number of feasible econometric methodologies will be limited. There is no doubt that future studies on balance of payments flows and determinations will enormously benefit from the results of this study in order to extend the empirical and quantitative analysis of determining separately the current and capital account as a basis for the overall balance of payments for Namibia.

\section{References}

Bank of Namibia. (Various issues). Annual Report. Windhoek: Bank of Namibia.

Bank of Namibia. (Various issues). Quarterly Bulletin. Windhoek: Bank of Namibia.

Carbaugh, R.J. (2008). International Economics, Cengage Learning:

Clausen, J.R., and Magda, K. (2004). On the Relation between the Current and Financial accounts: Evidence from Nine Industrial Countries. IMF Working Paper.

Corden, W.M. (2007). Those Current Account Imbalances: A Skeptical View. The World Economy, 30: 363-382. http://dx.doi.org/10.1111/j.1467-9701.2007.01000.x

Eita, J.H., \& Jordaan, A.C. (2010). A Causality Analysis between Financial Development and Economic Growth in Botswana. African Finance Journal, 12(1): $72-89$.

Freytag, A. (2008). Balance of Payments Dynamics, Institutions and Economic Performance in South Africa: A Policy Oriented Study, TIPS Working Paper, Working Paper Series 2008-04. Trade and Industrial Policy Strategies.

Harris, R.I.D. (1995). Using Cointegration Analysis in Econometric Modelling. London: Prentice Hall/Harvester Wheatsheaf.

Iley, R. A., \& Lewis, M. K. (2007). Untangling the US Deficit - Evaluating Causes, Cures and Global Imbalances, Cheltenham and Northampton, MA: Edward Elgar,

Imam, P. (2008). Rapid Current Account Adjustments: Are Microstates Different? IMF Working Paper, WP/08/233, International Monetary Fund.

Iyambo, A.P., \& Kalenga, P. (2002). Assessing the Impact of the EU-RSA TDCA on Namibia's Public Revenue. Bank of Namibia Working Paper, No. 3, Bank of Namibia.

Johansen, S. (1998). Statistical Analysis of Cointegrating Vectors. Journal of Economic Dynamics and Control, 12, p. 231- 254. http://dx.doi.org/10.1016/0165-1889(88)90041-3

Johansen, S. (1995). Likelihood Based Inferences in Cointegrated Vector Autoregressive Models. Oxford: Oxford University Press. http://dx.doi.org/10.1093/0198774508.001.0001

Kallon, K.M. (1994). An Econometric Analysis of Inflation in Sierra Leone. Journal of African Economies, 3(2): $1999-230$.

Miyajima, K. (2007). What do we know about Namibia's Competitiveness. IMF Working Paper, WP/07/191, International Monetary Fund.

Sims, A. C. (1980). Macroeconomics and Reality. Econometrica, 48(1): 1 - 48. http://dx.doi.org/10.2307/1912017

Wang J.Y. Masha, I., Shirono, K., \& Harris, L. (2007). Common Monetary Area in Southern Africa: Shocks, Adjustment, and Policy Responses, IMF Working Paper, WP/07/158. International Monetary Fund. 


\section{Notes}

Note 1. The BOP consists of three types of accounts, namely the current, capital and financial accounts. The current account refers to the monetary value of international flows related with transactions in goods, services and income flows. The capital and financial accounts consist of both private sector and reserve bank transactions.

Note 2. These structural features typically include lumpiness of investments, geographic dependency on an anchored bigger diversified economy, and fairly developed capital markets.

Note 3. This provides the advantage of easily calculating the development of the real exchange rate by calculating domestic price indices $\mathrm{e}_{\mathrm{real}}=\mathrm{P}_{\mathrm{T}} / \mathrm{P}_{\mathrm{N}}$.

Table 1. Unit root test results

\begin{tabular}{|c|c|c|c|}
\hline & & LEVELS & FIRST DIFFERENCE \\
\hline Variable & Model & $\mathrm{ADF}$ & $\mathrm{ADF}$ \\
\hline$B O P_{t}$ & $\begin{array}{l}\text { Constant } \\
\text { Constant \& trend } \\
\text { none }\end{array}$ & $\begin{array}{l}-4.91 * * * \\
-6.16 * * * \\
-2.50 * *\end{array}$ & $\begin{array}{l}-6.95 * * * \\
-6.94 * * * \\
-7.02 * * *\end{array}$ \\
\hline $\ln D C_{t}$ & $\begin{array}{l}\text { Constant } \\
\text { Constant \& trend } \\
\text { none }\end{array}$ & $\begin{array}{l}-0.25 \\
-4.13^{* *} \\
6.67\end{array}$ & $\begin{array}{l}-10.29 * * * \\
-10.13^{* * *} \\
-0.58\end{array}$ \\
\hline$F B_{t}$ & $\begin{array}{l}\text { Constant } \\
\text { Constant \& trend } \\
\text { none }\end{array}$ & $\begin{array}{l}-1.67 \\
-1.55 \\
-1.31\end{array}$ & $\begin{array}{l}-6.35 * * * \\
-6.34 * * * \\
-6.40 * * *\end{array}$ \\
\hline $\ln E R_{t}$ & $\begin{array}{l}\text { Constant } \\
\text { Constant \& trend } \\
\text { none }\end{array}$ & $\begin{array}{l}-2.33 \\
-2.27 \\
0.25\end{array}$ & $\begin{array}{l}-4.59 * * * \\
-4.59 * * * \\
-4.64 * * *\end{array}$ \\
\hline $\ln Y_{t}$ & $\begin{array}{l}\text { Constant } \\
\text { Constant \& trend } \\
\text { none }\end{array}$ & $\begin{array}{l}-0.74 \\
-3.29 \\
3.83\end{array}$ & $\begin{array}{l}-9.66 * * * \\
-9.54 * * * \\
-7.64 * * *\end{array}$ \\
\hline $\ln I R_{t}$ & $\begin{array}{l}\text { Constant } \\
\text { Constant \& trend } \\
\text { none }\end{array}$ & $\begin{array}{l}-2.25 \\
-2.65 \\
-0.81\end{array}$ & $\begin{array}{l}-4.26 * * * \\
-4.17 * * \\
-4.26 * * *\end{array}$ \\
\hline
\end{tabular}

Note: $* * * / * * / *$ indicate rejection of the hypothesis of nonstationary (there is unit root) at $1 \% / 5 \% / 10 \%$ significance level respectively.

Table 2. Cointegration test results

\begin{tabular}{|c|c|c|c|c|c|c|c|}
\hline \multicolumn{4}{|c|}{ TRACE TEST } & \multicolumn{3}{|c|}{ MAXIMUM EIGENVALUE TEST } \\
\hline$H_{0}$ & $H_{a}$ & $\lambda_{\text {trace }}$ & $5 \%$ critical value & $H_{0}$ & $H_{a}$ & $\lambda_{\max }$ & $5 \%$ critical value \\
\hline $\mathrm{r}=0$ & $\mathrm{r} \geq 1$ & $133.08^{*}$ & 103.85 & $\mathrm{r}=0$ & $\mathrm{r}=1$ & $50.54^{*}$ & 40.96 \\
\hline $\mathrm{r} \leq 1$ & $\mathrm{r} \geq 2$ & $82.54^{*}$ & 76.97 & $\mathrm{r}=1$ & $\mathrm{r}=2$ & 30.43 & 34.81 \\
\hline $\mathrm{r} \leq 2$ & $\mathrm{r} \geq 3$ & 52.10 & 54.08 & $\mathrm{r}=2$ & $\mathrm{r}=3$ & 18.57 & 28.59 \\
\hline $\mathrm{r} \leq 3$ & $\mathrm{r} \geq 4$ & 33.54 & 35.19 & $\mathrm{r}=3$ & $\mathrm{r}=4$ & 14.69 & 22.30 \\
\hline $\mathrm{r} \leq 4$ & $\mathrm{r} \geq 5$ & 18.84 & 20.26 & $\mathrm{r}=4$ & $\mathrm{r}=5$ & 13.87 & 15.89 \\
\hline $\mathrm{r} \leq 5$ & $\mathrm{r} \geq 6$ & 4.98 & 9.16 & $\mathrm{r}=5$ & $\mathrm{r}=6$ & 4.97 & 9.16 \\
\hline
\end{tabular}

$*$ Denotes rejection of the null of no cointegration at $5 \%$ significant level. 
Table 3. Cointegration test results

\begin{tabular}{|c|c|c|}
\hline VARIABLES & \multicolumn{2}{|c|}{ COINTEGRATING EQUATION } \\
\hline & $1^{\text {st }}$ cointegrating $\quad\left(B O P_{t}\right)$ equation & $2^{\text {nd }}$ cointegrating $\left(\ln D C_{t}\right)$ equation \\
\hline$\triangle B O P_{t}$ & $\begin{array}{l}-0.80 \\
(-1.76)\end{array}$ & 0.00 \\
\hline$\Delta \ln D C_{t}$ & $\begin{array}{c}-0.00005 \\
(-3.03)\end{array}$ & $\begin{array}{c}0.09 \\
(6.67)\end{array}$ \\
\hline$\Delta F B_{t}$ & 0.00 & $\begin{array}{c}2.82 \\
(2.70)\end{array}$ \\
\hline$\Delta \ln E R_{t}$ & 0.00 & 0.00 \\
\hline$\Delta \ln Y_{t}$ & 0.00 & $\begin{array}{c}0.06 \\
(2.84)\end{array}$ \\
\hline$\Delta \ln I R_{t}$ & 0.00 & 0.00 \\
\hline & $\begin{array}{l}\text { Likelihood ratio test for binding restric } \\
\chi^{2}(7): \\
\text { Probability }^{\mathrm{a}}:\end{array}$ & ion $(\operatorname{rank}=2)$ is \\
\hline
\end{tabular}

Notes: The t-statistics are in brackets.

The likelihood ratio test is for both long-run and the above loading matrices restrictions.

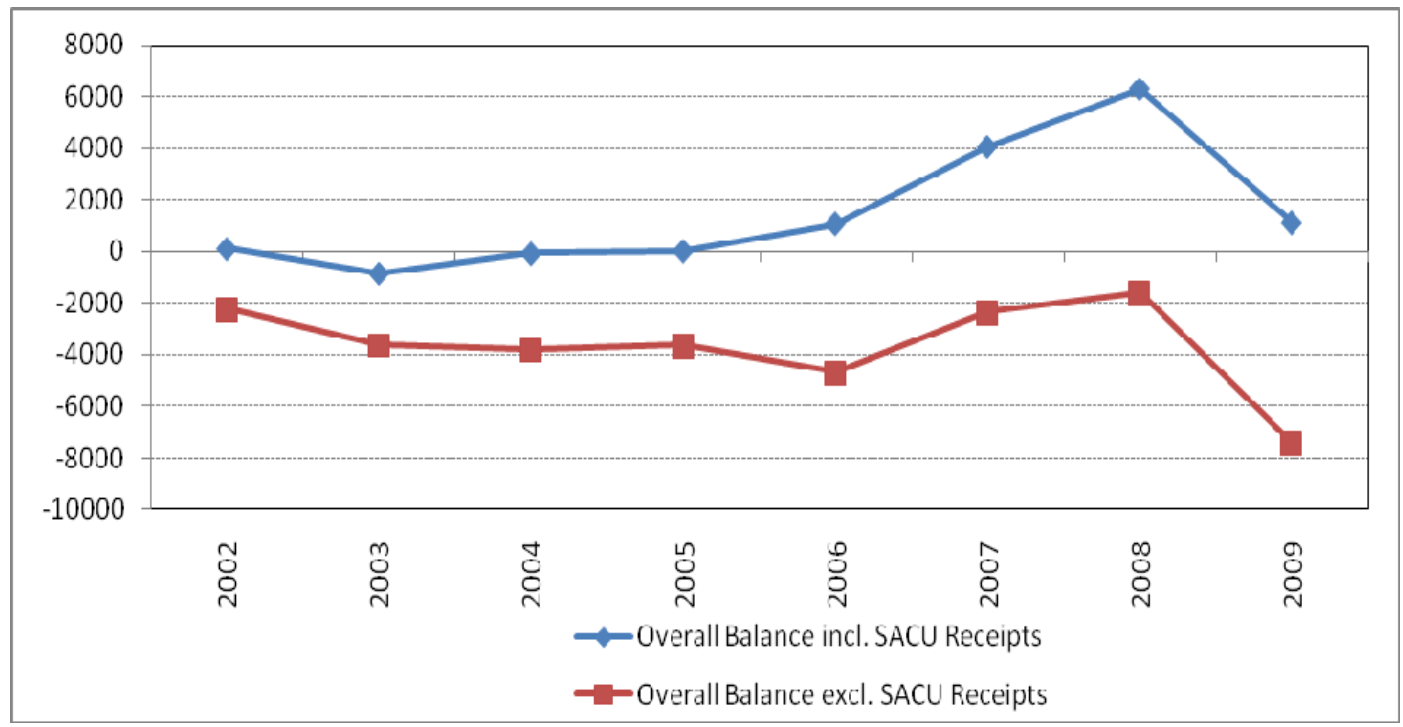

Figure 1. Overall Balance of Payments (Namibia dollar N\$ millions)

Source: Data obtained from Bank of Namibia: Annual Report and Quarterly Bulletins 


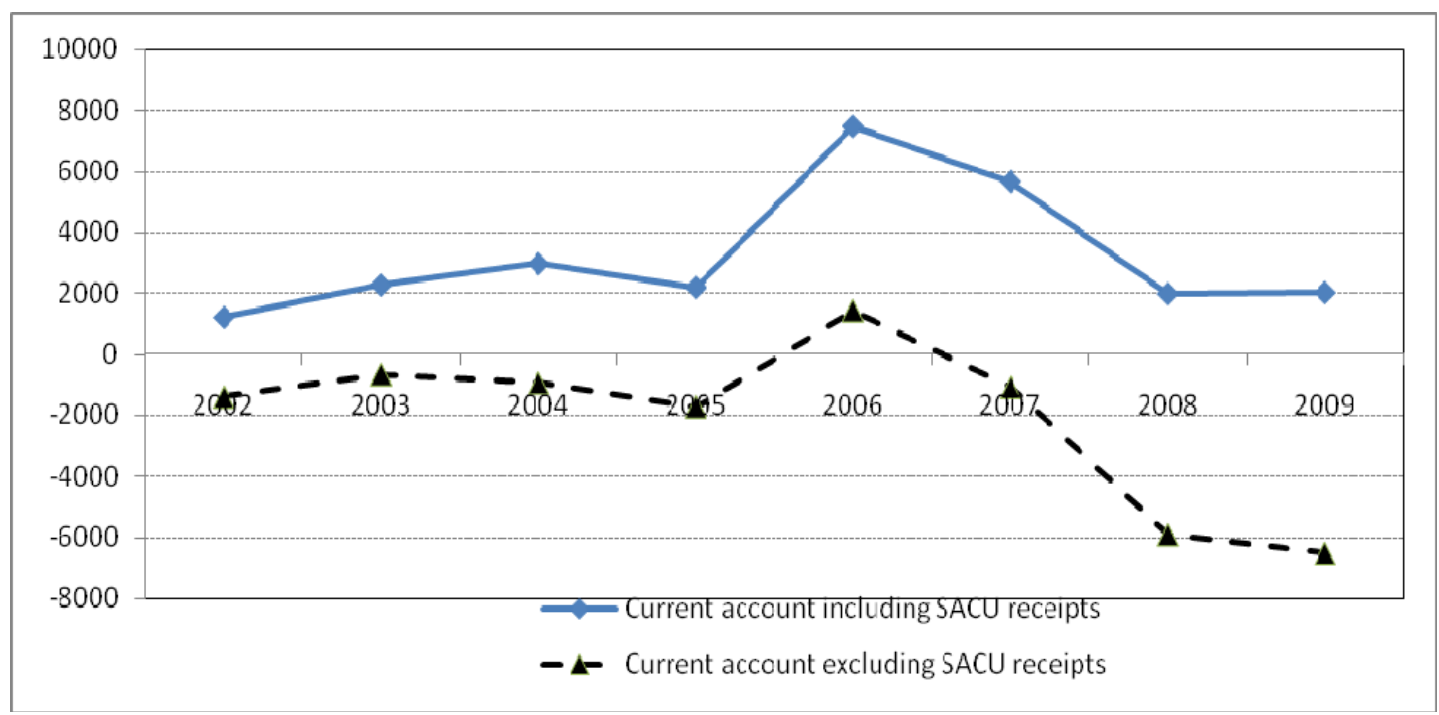

Figure 2. Current Account (N\$ millions)

Source: Data obtained from Bank of Namibia: Annual Report and Quarterly Bulletin

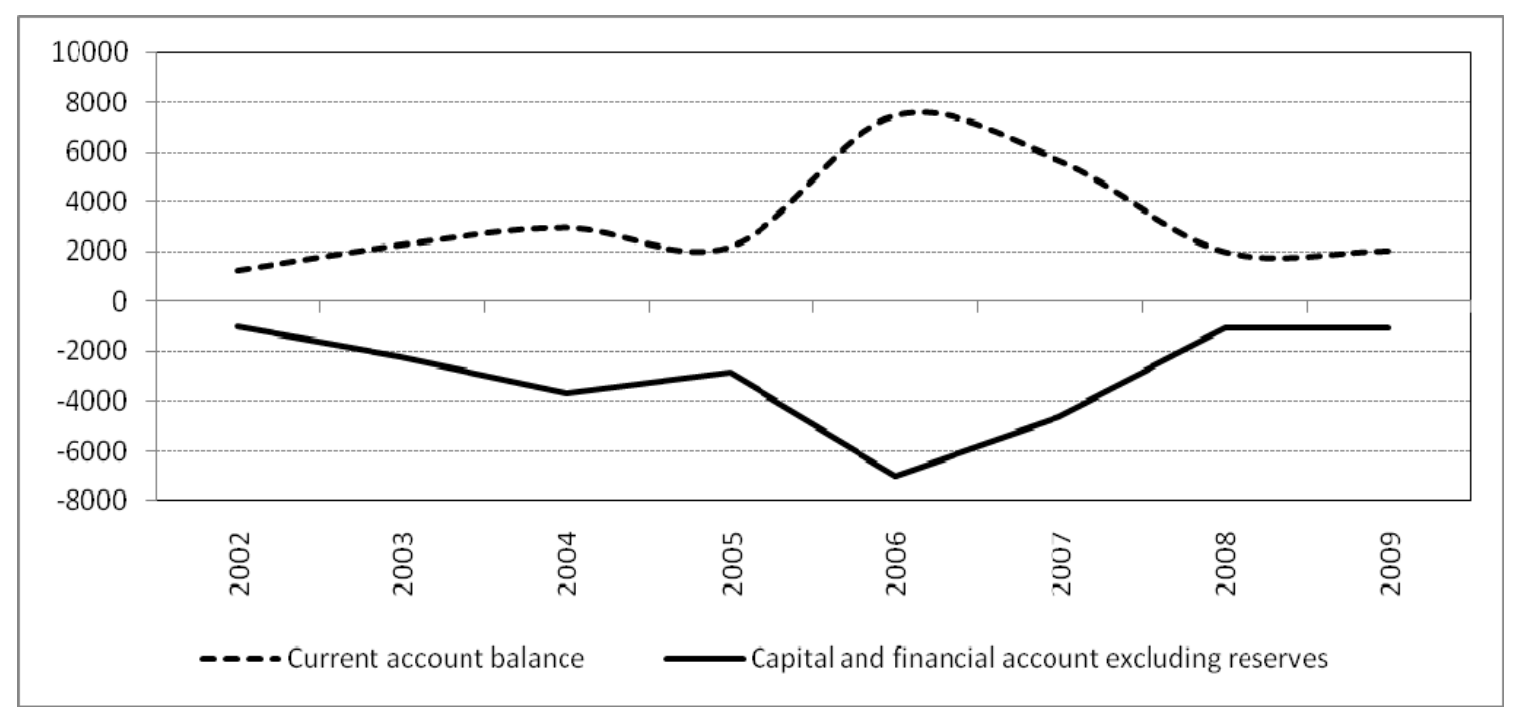

Figure 3. Balance of Payments accounts (current account balance and capital and financial account excluding reserves)

Source: Data obtained from Bank of Namibia: Annual Report and Quarterly Bulletin 